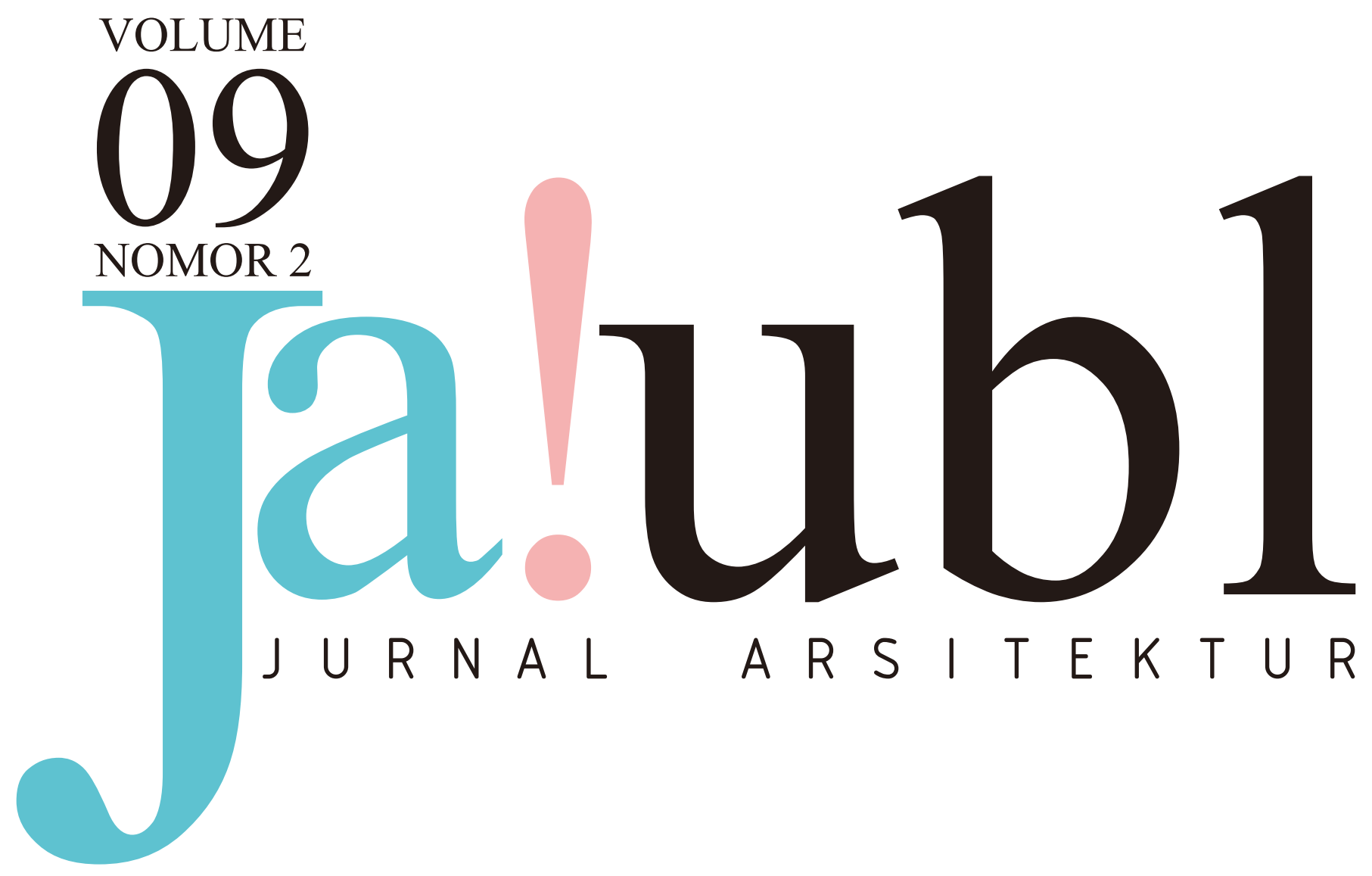


JA!UBL - Jurnal Arsitektur

Terbit dua kali setahun pada bulan Januari dan Juli. Diterbitkan oleh Program Studi Arsitektur Fakultas Teknik Universitas Bandar Lampung. JA!UBL merupakan media pendokumentasian, sharing, dan publikasi karya ilmiah yang berisi karya-karya riset ilmiah mengenai bidang ilmu perancangan arsitektur dan bidang ilmu lain yang sangat erat kaitannya seperti perencanaan kota dan daerah, desain interior, perancangan lansekap, dan sebagainya.

ISSN: 2087-2739

\section{PELINDUNG}

Dr. Ir.H.M.Yusuf Barusman, M.B.A. (Universitas Bandar Lampung)

\section{PENASEHAT}

Dr. Ir. Hery Riyanto, M.T. (Universitas Bandar Lampung)

PENANGGUNG JAWAB

Ir. Tjetjeng Sofjan S., M.M., M.T. (Universitas Bandar Lampung)

\section{PIMPINAN REDAKSI}

Dr.Eng. Haris Murwadi, S.T., M.T.

\section{REDAKSI PELAKSANA}

Shofia Islamia Ishar, S.T., M.T.

Dadang Hartabela, S.T., M.T.

Ai Siti Munawaroh, S.Pd., M.I.L.

Indyah Kumoro Wardani, S.T., IAI

\section{DEWAN REDAKSI}

Prof. Dr. Julaihi Wahid (Universitas Sains Malaysia)

Prof. Dr. Ir. H. Slamet Tri Sutomo, M.S (Universitas Hasanuddin)

Prof. Ir. Totok Rusmanto, M.Eng. (Universitas Diponegoro)

Prof. Dr. Ing. Ir Gagoek Hardiman. (Universitas Diponegoro)

Dr.Eng. Fritz Akhmad Nuzir, S.T., M.A.(L.A.) (Universitas Bandar Lampung)

David Hutama, ST., M.Eng (Universitas Pelita Harapan)

\section{MITRA BESTARI}

Dr. Ir. Budi Prayitno, M.Eng. (Universitas Gajah Mada)

Dr. Eng. Ir. Ahmad Sarwadi, M.Eng (Universitas Gajah Mada)

Prof. Dr. T. Yoyok Wahyu Subroto, M.Eng. Ph. D. (Universitas Gajah Mada)

Dr.Eng. Fritz Akhmad Nuzir, S.T., M.A. (L.A.) (Universitas Bandar Lampung)

Prof. Ir. Liliany Sigit Arifin, M.Sc., Ph. D (Universitas Petra)

Dr. Budi Faisal (Institut Teknologi Bandung)

Dr.Eng. Agus Hariyadi, S.T., M.Sc. (Universitas Gajah Mada)

\section{TIM GRAFIS DESAIN}

Satrio Agung Perwira

B. Chrysvania Artemisia

\section{ALAMAT REDAKSI}

Program Studi Arsitektur Fakultas Teknik Universitas Bandar Lampung

Jalan Zainal Abidin Pagar Alam Nomor. 26 Labuhanratu, Bandarlampung, 35142

Telp. $\quad:$ :0721-773847

E-mail : : editor.j@ubl.ac.id

Homepage : ubl.ac.id 


\section{Daftar Isi Artikel}

01-06 Analisis Penerapan Art Deco pada Rumah di Bandung Periode Perang Dunia I-II Studi Kasus: Tiga Villa dan Perumahan Dosen UPI FADILASARI, Dewi

07-12 Tipologi Bentuk Atap pada Arsitektur Jawa ROOSANDRIANTINI, Josephine; SANTOSO, Angelina Novemita; AMBARWATI, Catherina Novita

13-18 Identifikasi Respon Pengunjung mengenai Keberadaan Desa Wisata Taman Purbakala Pugungraharjo Lampung HARTABELA, Dadang; MASITO, Yuni

19-26 Fenomena Terbentuknya Ruang Spatio-Temporal di Kawasan Stadion Pahoman Bandarlampung WIBAWA, M. Shubhi Yuda

27-32 Identifikasi Area Berpotensi Macet di Kawasan Pendidikan Jl. Z.A. Pagar Alam Bandarlampung PERWIRA, Satrio Agung; MURWADI, Haris; MUNAWAROH, Ai Siti; ISHAR, Shofia Islamia

33-40 Manfaat Ruang Terbuka dan Hubungannya dengan Kegiatan Interaksi Sosial Studi Kasus: Perumahan Nusa Tamalanrea Indah Makassar NURHIJRAH; WIKANTARIA, Ria 


\title{
Identifikasi Area Berpotensi Macet di Kawasan Pendidikan Jl. Z.A. Pagar Alam Bandarlampung
}

\author{
Satrio Agung Perwira ${ }^{1 *}$, Haris Murwadi ${ }^{2}$, Ai Siti Munawaroh ${ }^{3}$, Shofia Islamia Ishar ${ }^{4}$ \\ ${ }^{1}$ Mahasiswa, Program Studi Arsitektur, Universitas Bandar Lampung \\ ${ }^{234}$ Dosen, Program Studi Arsitektur, Universitas Bandar Lampung \\ *Penulis Korespondensi: satrioagungp21@gmail.com; Telp. +62 896-0730-2538
}

\begin{abstract}
Abstrak:
Jalan raya merupakan jalan utama yang dapat menghubungkan satu kawasan ke kawasan lainnya. Salah satu jalan raya di Bandarlampung yang memiliki peran sangat penting yaitu J1. Z.A. Pagar Alam. Jalan ini menghubungkan kawasan-kawasan penting di Kota Bandarlampung. Beberapa titik pada jalanan ini selalu terdapat kemacetan, khususnya pada jam-jam sibuk. Salah satu indikasi kemacetan yang terjadi adalah kendaraan yang ada saat ini sudah sangat banyak namun luasan jalan raya belum menyesuaikannya. Penyebab lainnya juga adalah perilaku pengguna jalan raya yang memarkirkan kendaraan mereka yang illegal. Identifikasi ini bertujuan untuk menganalisa kemacetan yang ada di kawasan pendidikan di Jl. Z.A. Pagar Alam. Metode yang digunakan yaitu deskriptif kualitatif. Data diperoleh melalui observasi dan dokumentasi. Data dianalisis dengan membandingkan keadaan dengan peraturan yang berlaku. Hasil penelitian menunjukan 1) area parkir illegal pada kawasan ini merupakan tindakan yang didasari oleh tidak tersedianya lahan parkir yang cukup; 2) parkir ilegal di area ini juga dikarenakan bangunan pendukung seperti warung makan, tempat print dan photocopy yang tidak memiliki lahan parkir sehingga menggunakan bagian jalan raya untuk parkir illegal; 3) Kemacetan yang terjadi pada beberapa titik ini didasari oleh fenomena yang disebut bottleneck atau penyempitan jalur yang pada akhirnya membuat pengendara harus mengambil jalur tengah atau tindakan bergeser atau zig zag; 4) Parkir illegal pada beberapa titik di kawasan ini merupakan area yang tidak seharusnya ada tempat parkir illegal dikarenakan beberapa titik seperti pada titik A, C, D, dan E merupakan area dengan pertemuan jalan penghubung lainnya yang menjadikan area ini cukup terhambat pergerakan kendaraannya. Solusi untuk mengatasi permasalahan kemacetan yaitu: dilakukan pelebaran jalan, diberikan kantung parkir, merelokasi pedagang pinggir jalan ke jalan gang, dan memberikan ruang pada area kendaraan yang akan berbalik arah.
\end{abstract}

Kata Kunci: aksesibilitas; parkir ilegal; jalan raya; kemacetan

\section{Latar Belakang}

Jalan raya adalah jalur - jalur tanah di atas permukaan bumi yang dibuat oleh manusia dengan bentuk, ukuranukuran dan jenis konstruksinya sehingga dapat digunakan untuk menyalurkan lalu lintas orang, hewan dan kendaraan yang mengangkut barang dari suatu tempat ke tempat lainnya dengan mudah dan cepat (Clarkson \& Oglesby, 1999). Pada umumnya di kota-kota besar di Indonesia mengalami masalah lalu lintas yang sama pada jalan utama mereka, yaitu kemacetan.

Lalu- lintas tergantung kepada kapasitas jalan, banyaknya lalu- lintas yang ingin bergerak, tetapi kalau kapasitas- jalan tidak dapat menampung, maka lalu- lintas yang ada akan terhambat dan akan mengalir sesuai dengan kapasitas jaringan jalan maksimum (Sinulaga, 1999). Kemacetan lalu lintas pada ruas jalan raya terjadi saat arus kendaraan lalu lintas meningkat seiring bertambahnya permintaan perjalanan pada suatu periode tertentu serta jumlah pemakai jalan melebihi dari kapasitas yang ada (Meyer \& Miller, 1984). Dapat disimpulkan bahwa penyebab kemacetan berasal dari berbagai faktor yang saling terhubung seperti, kedisiplinan yang kurang sampai pertumbuhan kendaraan yang tidak bisa di imbangi oleh pertumbuhan prasarana jalan.

Kemacetan adalah kondisi dimana arus lalu lintas yang lewat pada ruas jalan yang ditinjau melebihi kapasitas rencana jalan tersebut yang mengakibatkan kecepatan bebas ruas jalan tersebut mendekati atau melebihi $0 \mathrm{~km} / \mathrm{jam}$ sehingga menyebabkan terjadinya antrian. Pada saat terjadinya kemacetan, nilai derajat kejenuhan pada ruas jalan akan ditinjau dimana kemacetan akan terjadi bila nilai derajat kejenuhan mencapai lebih dari 0,5 (DPUDJBM, 1997). Kemacetan lalu lintas terjadi bila pada kondisi lalu lintas di jalan raya mulai tidak stabil, kecepatan operasi menurun relatif cepat akibat adanya hambatan yang timbul dan kebebasan bergerak relatif kecil (Sumadi, 2006). Lalu-lintas tergantung kepada kapasitas jalan, banyaknya lalu- lintas yang ingin bergerak, tetapi kalau kapasitas jalan tidak dapat menampung, maka lalu- lintas yang ada akan terhambat dan akan mengalir sesuai dengan kapasitas jaringan jalan maksimum (Sinulaga, 1999). Kemacetan lalu lintas pada ruas jalan raya terjadi saat arus 
kendaraan lalu lintas meningkat seiring bertambahnya permintaan perjalanan pada suatu periode tertentu serta jumlah pemakai jalan melebihi dari kapasitas yang (Meyer \& Miller, 1984). Volume lalu lintas adalah banyaknya kendaraan yang melewati suatu titik atau garis tertentu pada suatu penampang melintang jalan. Data pencacahan volume lalu lintas adalah informasi yang diperlukan untuk fase perencanaan, desain, manajemen sampai pengoperasian jalan (Sukirman, 1999).

Kerugian yang diderita akibat dari masalah kemacetan ini apabila dikuantifikasikan dalam satuan moneter sangatlah besar, yaitu kerugian karena waktu perjalanan menjadi panjang dan makin lama, biaya operasi kendaraan menjadi lebih besar dan polusi kendaraan yang dihasilkan makin bertambah. Pada kondisi macet kendaraan merangkak dengan kecepatan yang sangat rendah, pemakaian BBM menjadi sangat boros, mesin kendaraan menjadi lebih cepat aus dan buangan kendaraan yang dihasilkan lebih tinggi kandungan konsentrasinya. Pada kondisi kemacetan pengendara cenderung menjadi tidak sabar yang menjurus ke tindakan tidak disiplin yang pada akhirnya memperburuk kondisi kemacetan lebih lanjut lagi (Santoso \& Idwan, 1997).

Berdasarkan UU No. 22 Tahun 2009 mengenai lalu lintas dan angkutan jalan, parkir adalah keadaan dimana kendaraan berhenti atau tidak bergerak dalam waktu tertentu dan ditinggalkan pengemudinya. Dalam penataan parkir perlu adanya perencanaan terlebih dahulu yakni mengenai lahan yang akan dimanfaatkan sebagai ruang parkir. Lahan parkir tersebut harus dioptimalkan secara baik agar dapat menampung dan melayani kebutuhan pengguna jasa parkir tersebut.

Ada aturan terkait larangan parker menurut UU No. 22 Tahun 2009 yaitu:

1. Sepanjang 6 meter sebelum dan sesudah tempat penyeberangan pejalan kaki atau tempat penyeberangan sepeda yang telah ditentukan.

2. Sepanjang 25 meter sebelum dan sesudah tikung antara jam dengan radius kurang dari 500 meter.

3. Sepanjang 50 meter sebelum dan sesudah jembatan. Sepanjang 100 meter sebelum dan sesudah perlintasan sebidang.

4. Sepanjang 6 meter sebelum dan sesudah akses bangunan gedung.

5. Sepanjang 6 meter sebelum dan sesudah hydrant atau keran pemadam kebakaran atau sumber air sejenis 7 . Sepanjang tidak menimbulkan kemacetan dan bahaya.

Identifikasi adalah proses pengenalan, menempatkan obyek atau individu dalam suatu kelas sesuai dengan karakteristik tertentu (Chaplin, 2008).

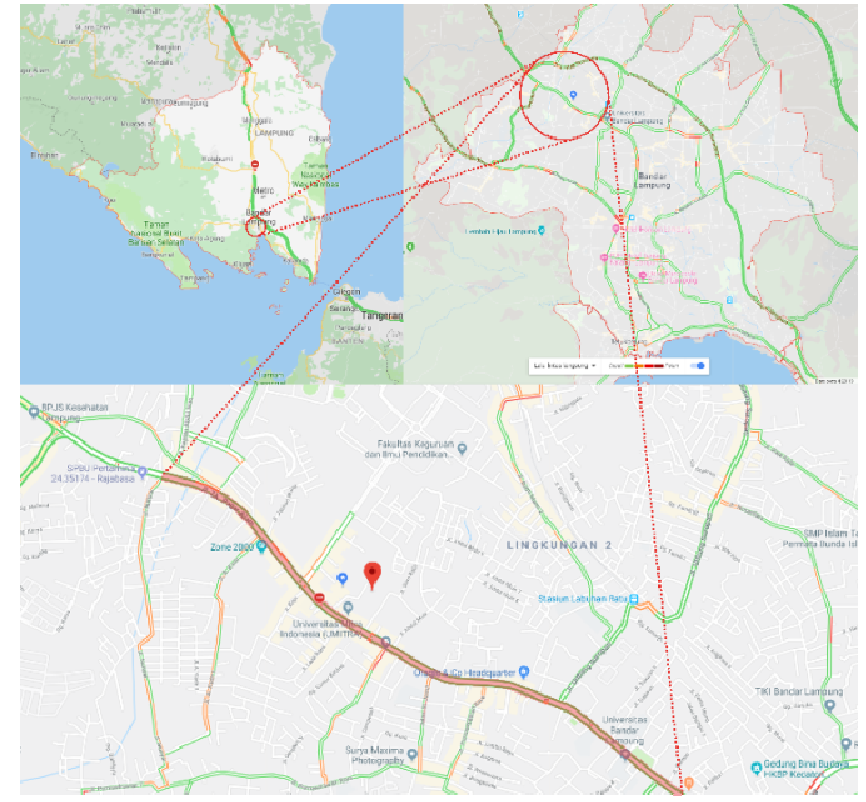

Gambar 1. Lokasi Identifikasi Jl. Z.A. Pagar Alam

Identifikasi dalam penelatian ini membahas tentang kemacetan pada jalan raya kota pada kawasan pendidikan. Penelitian ini membahas perilaku pengendara pada kawasan pendidikan yang menyebabkan kemacetan di Jl Z.A. Pagar Alam, dimana jalan raya ini merupakan penghubung kawasan-kawasan penting di Kota Bandarlampung. untuk lebih detainya, yang menjadi lokasi pengamatan adalah seperti pada gambar 1. Identifikasi ini dilakukan untuk mengidentifikasi penyebab kemacetan yang ada pada kawasan yang di bahas. 


\section{Metode Penelitian}

Penelitian ini menggunakan metode penelitian deskriptif kualitatif. Penelitian kualitatif dilakukan karena peneliti ingin mengeksplor fenomena-fenomena yang tidak dapat dikuantifikasikan yang bersifat deskriptif seperti proses suatu langkah kerja, formula suatu resep, pengertian-pengertian tentang suatu konsep yang beragam, karakteristik suatu barang dan jasa, gambar- gambar, gaya- gaya, tata cara suatu budaya, model fisik suatu artifak dan lain sebagainya (Satori, 2013).

\subsection{Metode Pengumpulan Data}

Data adalah bagian terpenting dari suatu penelitian, karena dengan data peneliti dapat mengetahui hasil dari penelitian tersebut. Pada penelitian ini, data diperoleh dari berbagai sumber, dengan menggunakan teknik pengumpulan data yang bermacam- macam dan dilakukan secara terus menerus sampai datanya jenuh. Sesuai dengan karakteristik data yang diperlukan dalam penelitian ini, maka teknik pengumpulan data yang dilakukan berupa observasi dan dokumentasi. Observasi dilakukan pada obyek penelitian sebagai sumber data dalam keadaan asli atau sebagaimana keadaan sehari- hari. Sedangkan, dokumentasi dilakukan penulis adalah berdasarkan foto yang penulis kumpulkan.

\subsection{Metode Analisis Data}

Analisis data dilakukan dengan metode komparasi berupa analisis fakta di lapangan yang dibandingkan dengan referensi dan peraturan yang berlaku.

\section{Hasil danPembahasan}

Lokasi yang dijadikan sebagai area identifikasi ini adalah di Jl. Z. A. Pagar Alam, tepatnya pada kawasan pendidikan. Kawasan pendidikan yang akan di identifikasi pada penulisan ini adalah jalan raya depan Universitas Bandarlampung sampai dengan jalan raya depan Universitas Darmajaya. Detail pada Gambar 2.

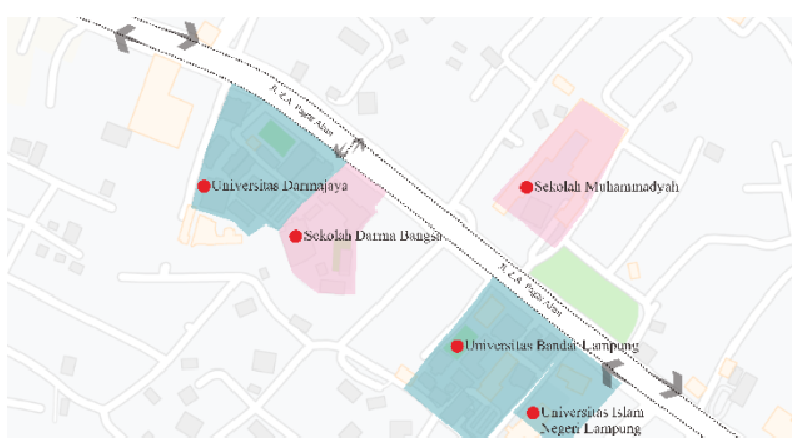

Gambar 2. Kawasan Identifikasi Jl. Z.A. Pagar Alam

Yang menjadi kawasan identifikasi ini merupakan kawasan yang sekitarnya merupakan lokasi dari beberapa sekolah dan juga universitas. Sebagai kawasan pendidikan tentunya sangat melekat juga kepada beberapa bangunan pendukung komersil seperti tempat print, photocopy, warung makan, toko alat tulis dan lainnya. Bangunan pendukung ini tentunya membutuhkan area parkir sebagai fasilitas pengunjungnya namun bangunan-bangunan ini tidak memiliki sarana tersebut dan juga jarak bangunan pada jalan raya didepannya tidak ada garis sempadan jalan, sehingga para pengunjung memarkirkan kendaraan mereka di jalan raya. Lebar jalan raya ini sendiri kurang dari 9 meter dengan pola 3 ruas jalur sirkulasi.

Foto yang didapatkan merupakan foto dari titik-titik parkir ilegal yang ada pada kawasan identifikasi seperti pada Gambar 3.

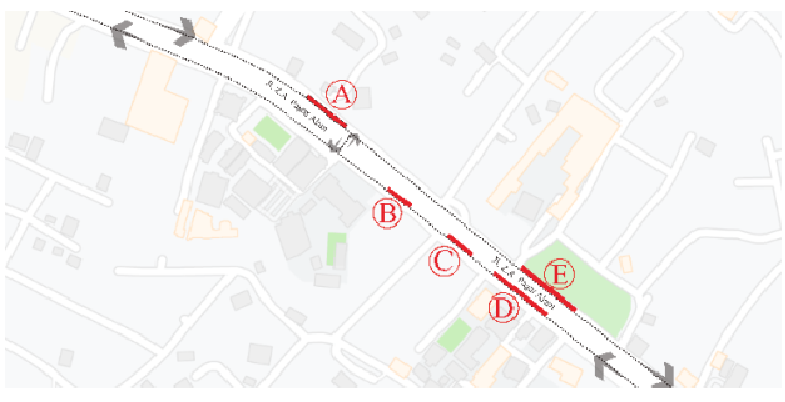

Gambar 3. Titik Parkir Liar di Kawasan Identifikasi 
Keterangan Gambar 3:

A. Parkir ilegal di depan pertokoan yang melayani photocopy, print, toko alat tulis dan warung makan.

B. Parkir ilegal di sisi jalan sebelum Sekolah Darma Bangsa, biasanya pengendara yang memarkirkan kendaraan area ini adalah beberapa orang tua murid yang menunggu anaknya untuk dijemput.

C. Parkir ilegal di sisi jalan depan Dunkin Donut, pemarkir ilegal ini biasanya adalah pelanggan yang tidak mendapatkan ruang parkir di dalam area Dunkin Donut.

D. Parkir ilegal di sisi jalan depan Universitas Bandar Lampung, biasanya pengguna ini adalah mahasiswa yang tidak mendapatkan ruang parkir di area kampus.

E. Parkir ilegal di sisi jalan di depan area pemakaman disamping sekolah Muhammadyah Bandar lampung yang pada tepi pemakaman merupakan warung makan, tempat print dan photocopy.

Dari data yang sudah dipaparkan, didapatkan skema lalu lintas pada titik-titik yang di duga menjadi penyebab kemacetan di kawasan identifikasi

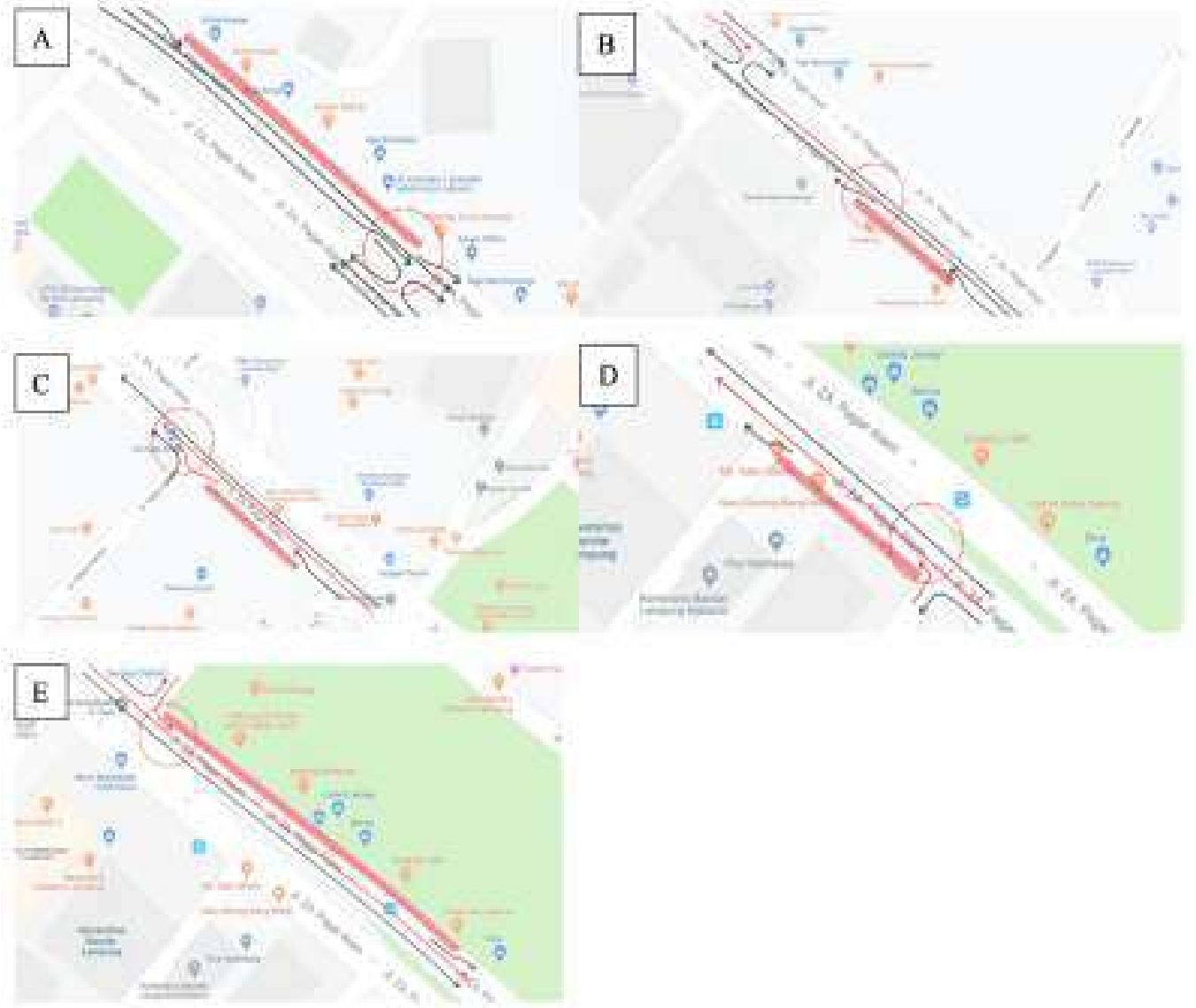

Gambar 4. Skema Sirkulasi pada Kawasan Identifikasi

Penjelasan:

A. Pada skema ini didapatkan bahwa parkir illegal pada area ini menimbulkan penyempitan jalan atau yang biasa di sebut dengan bottleneck yang menyebabkan area yang dibulati warna merah itu mengalami kemacetan dikarenakan penumpukan kendaraan. Juga dikarenakan itu merupakan area pertemuan kendaraaan dari beberapa arah lalu lintas.

B. Pada skema ini didapati bahwa parkir ilegal di area ini menyebabkan penyempitan jalan yang biasa di sebut juga dengan bottleneck yang menyebabkan area yang dibulati warna merah menjadi cukup menghambat kendaraan untuk melintas.

C. Pada skema ini didapati bahwa parkir ilegal di area ini juga menimbulkan penyempitan jalur kendaraan dan juga dikarenakan merupakan pertemuan dengan jalan gang membuat area yang dibulati warna merah menjadi terganggu aksesnya.

D. Pada skema ini didapati bahwa area ini yang dibulati warna merah menjadi area yang cukup terhambat akesnya dikarenakan parkir ilegal yang berada dekat dengan akses keluar masuk Universitas Bandar Lampung dan jalan raya di depannya. 
E. Pada skema ini didapati bahwa area yang dibulati warna merah menjadi area yang cukup terhambat aksesnya dikarenakan parkir ilegal yang berada dekat dengan akses keluar masuk Sekolah Muhammadyah dan jalan raya di depannya.

Dalam identifikasi yang sudah dilakukan didapatkan beberapa permasalahan parkir illegal. Solusi yang tepat dalam pemecahan beberapa masalah ini adalah sebagai berikut:

1. Dilakukan pelebaran jalan.

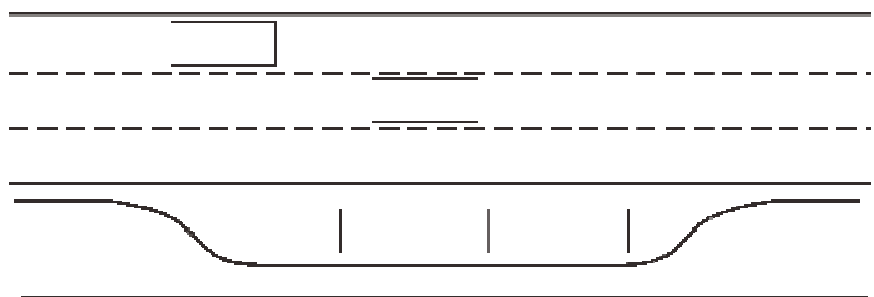

Gambar 5. Skema Solusi 1

2. Diberikan kantung parkir pada area ini.

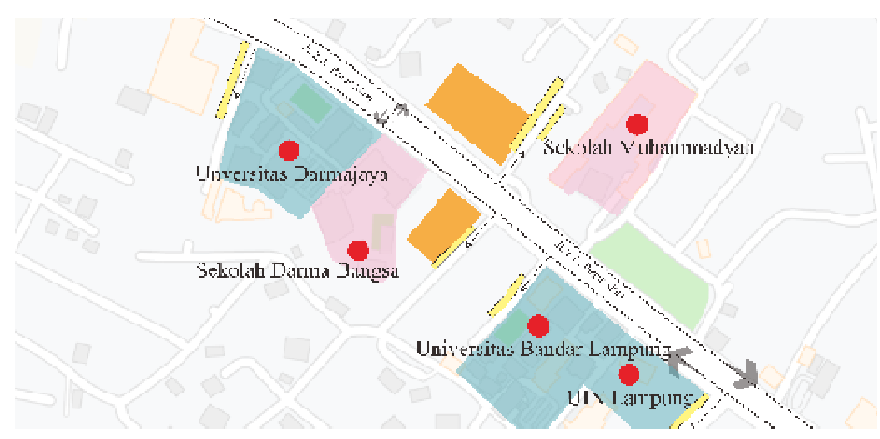

Gambar 6. Skema Solusi 2

3. Merelokasi toko-toko di pinggir jalan pada area gang.

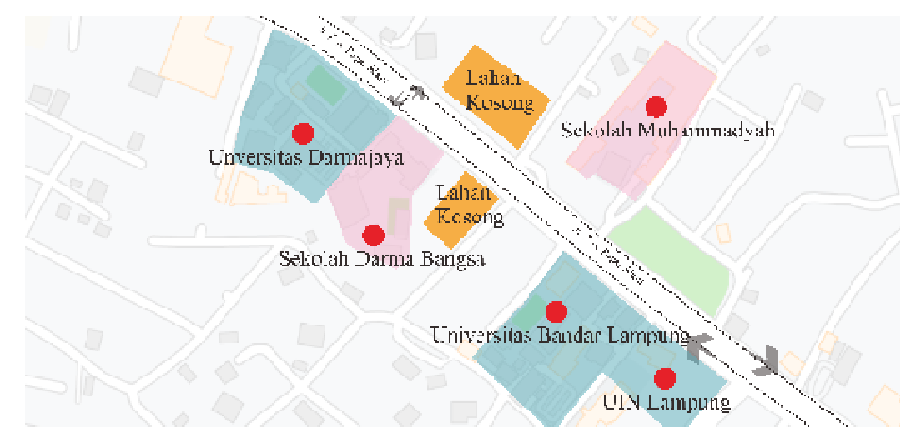

Gambar 7. Skema Solusi 3

4. Memberikan ruang pada area kendaraan yang akan berbalik arah.

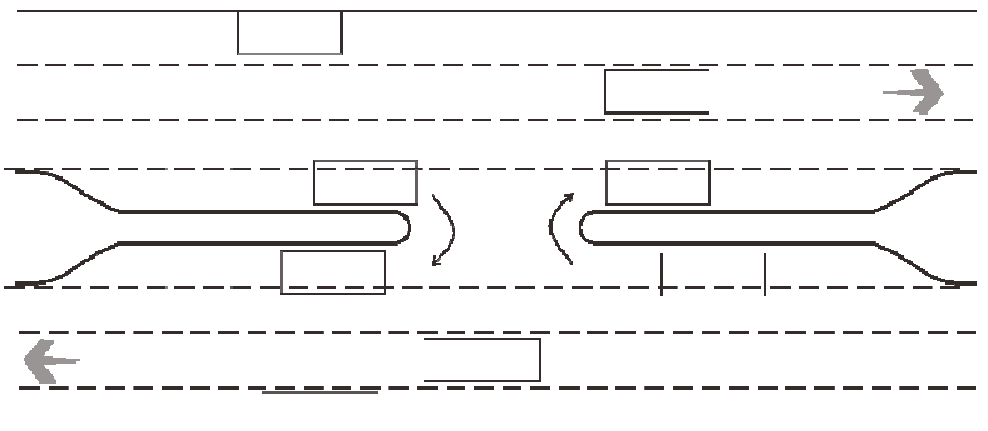

Gambar 8. SkemaSolusi 4 


\section{Kesimpulan}

Dari data yang sudah dikumpulkan dan juga pembahasan yang sudah di lakukan didapatkan beberapa poin sebagai berikut:

1. Area parkir illegal pada kawasan ini merupakan tindakan yang didasari oleh tidak tersedianya lahan parkir yang cukup.

2. Parkir ilegal di area ini juga dikarenakan bangunan pendukung seperti warung makan, tempat print dan photocopy yang tidak memiliki lahan parkir sehingga menggunakan bagian jalan raya untuk parkir ilegal.

3. Kemacetan yang terjadi pada beberapa titik ini didasari oleh fenomena yang disebut bottleneck atau penyempitan jalur yang pada akhirnya membuat pengendara arus mengambil jalur tengah atau tindakan bergeser atau zig zag.

4. Parkir illegal pada beberapa titik dikawasan ini merupakan area yang tidak seharusnya ada tempat parkir illegal dikarenakan beberapa titik seperti pada titik A, C, D, dan E merupakan area dengan pertemuan jalan penghubung lainnya yang menjadikan area ini cukup terhambat pergerakan kendaraannya.

5. Solusi untuk mengatasi permasalahan kemacetan yaitu: dilakukan pelebaran jalan, diberikan kantung parkir, merelokasi pedagang pinggir jalan ke jalan gang, dan memberikan ruang pada area kendaraan yang akan berbalik arah.

\section{UcapanTerimakasih}

Penulis mengucapkan terimakasih kepada Universitas Bandar Lampung yang telah memberikan fasilitas kepada penulis sehingga penelitian ini dapat diselesaikan. Penulis juga mengucapkan terimakasih kepada Redaksi Jurnal Arsitektur (JA) UBL yang telah membantu mereview dan mempublikasikan hasil penelitian ini.

\section{Daftar Pustaka}

Chaplin, J. (2008). Kamus Lengkap Psikologi. Jakarta: Raja Grafindo Persada.

Clarkson, \& Oglesby. (1999). Teknik Jalan Raya Jilid I. Jakarta: Gramedia.

DPUDJBM. (1997). Manual Kapasitas Jalan Indonesia (MKJI). Jakarta: Departemen Pekerjaan Umum Direktorat Jenderal Bina Marga.

Meyer, M., \& Miller, E. (1984). Urban Transportation Planning: A Decision Oriented Approach. New York: Mc Graw-Hill.

Santoso, \& Idwan. (1997). Perencanaan Sistem Angkutan Umum. Bandung: Badan Penerbit ITB.

Satori. (2013). Metodologi Penelitian Kualitatif. Bandung: Alfabeta.

Sinulaga, B. D. (1999). Pembangunan Kota Tinjauan Regional dan Lokal. Jakarta: Pustaka Sinar.

Sukirman, S. (1999). Dasar-Dasar Perencanaan Geometrik Jalan. Bandung: Penerbit Nova.

Sumadi. (2006). Kemacetan Lalu Lintas pada Ruas Jalan Veteran Kota Brebes. Semarang: Universitas Diponegoro. 


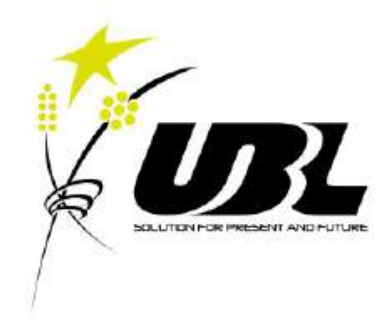

Published:

Program Studi Arsitektur Fakultas Teknik Universitas Bandar Lampung

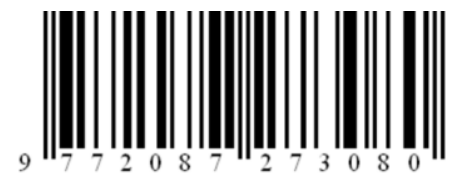

